\title{
Influence of Adsorbed Water on Surface State of Sodium Chloride Powder
}

\author{
Mamoru Kaino, Masatoshi Chikazawa and Takafumi Kanazawa \\ Department of Industrial Chemistry, Faculty of Technology, \\ Tokyo Metropolitan University; Fukazawa, Setagaya-ku, Tokyo, Japan
}

$\mathrm{NaCl}$ powder sample was prepared by the recipe mentioned in the previous paper. Water adsorption isotherms on the samples outgassed in the temperature range from $25^{\circ} \mathrm{C}$ to $360^{\circ} \mathrm{C}$ and their surface area values were determined. Effect of the amount of presorbed water on the isotherms was also tested.

Each of the isotherms showed a stepped rise in the adsorbed amount at the vapor pressure forming two layers completely. In the case of outgassing at $25^{\circ} \mathrm{C}$, reproducible isotherms were obtained for the repeated adsorption up to forming three layers. The sample outgassed after forming eight layers showed $20 \%$ decrease in the monolayer capacity. When the presorbed amount exceeded the amount necessary to form 2.7 layers, a surface area of the sample began to decrease.

The outgassing at temperatures above $200^{\circ} \mathrm{C}$ decreased the height of a stepped rise of the isotherm, and the subsequent outgassing at $25^{\circ} \mathrm{C}$ lowered the water adsorption ability. Corresponding to the above phenomena, the surface area of the sample more decreased by adsorbing water than that of the sample untreated.

（日本化学会誌, 1973, p. 917～922）

\section{$\mathrm{NH}_{3}-\mathrm{CO}_{2}-\mathrm{H}_{2} \mathrm{O}$ 三成分系気 液 平衡}

\author{
(1972 年 5 月 19 日 受 理)
}

柳沢譲・原 納 淑 郎・井本 立也*

尿素合成プロセスにおいて分離器ならびに凝縮器の操作に関する基礎的データを得るため, 圧力 20 $\mathrm{kg} / \mathrm{cm}^{2}$, 温度 $100 \sim 140^{\circ} \mathrm{C}$ での $\mathrm{NH}_{3}-\mathrm{CO}_{2}-\mathrm{H}_{2} \mathrm{O}$ 三成分系気液平衡を実測し, 等温溶解度曲線を求める とともに気液平衡関係を推算できる実験式を求めた。

液相の活量係数 $\gamma_{\mathrm{i}}$ は, つぎの van Laar の 2-Suffix 式で与兄られる。

$$
\begin{aligned}
& \log \gamma_{\mathrm{NH}_{3}}=\left(-0.438 x_{\mathrm{CO}_{2}}^{2}+0.450 x_{\mathrm{H}_{2} \mathrm{O}}^{2}-10.0 x_{\left.\mathrm{CO}_{2} x_{\mathrm{H}_{2} \mathrm{O}}\right) /\left(x_{\mathrm{NH}_{3}}-4.80 x_{\mathrm{CO}_{2}}+3.74 x_{\mathrm{H}_{2} \mathrm{O}}\right)^{2}}\right. \\
& \log \gamma_{\mathrm{H}_{2} \mathrm{O}}=\left(0.00859 x_{\mathrm{NH}_{3}}^{2}-3.3486 x_{\mathrm{CO}_{2}}^{2}-0.7058 x_{\mathrm{NH}_{3}} x_{\mathrm{CO}_{2}}\right) /\left(x_{\mathrm{H}_{2}} \mathrm{O}+0.2675 x_{\mathrm{NH}_{3}}-1.283 x_{\mathrm{CO}_{2}}\right)^{2}
\end{aligned}
$$

上式で得られる計算値と実測值とのよい一致から, $\mathrm{NH}_{3}, \mathrm{CO}_{2}$ および $\mathrm{H}_{2} \mathrm{O}$ の液 相内含有モル分率 $x_{\mathrm{i}}$ がわかれば，本実験温度範囲内で，気相成分のモル分率 $y_{\mathrm{i}}$ が算定できることがわかった。

なお，これらの計算に必要なパラメーター $\left(z_{\mathrm{i}} / P_{\mathrm{i}}^{0}\right) \pi\left[\left\{=r_{\mathrm{i}}\left(x_{\mathrm{i}} / y_{\mathrm{i}}\right)\right\}\right]$ は，本実験温度範囲内でつぎの ような簡単な温度の関数として表わされる。

$$
\begin{aligned}
& \log \left(z_{\mathrm{NH}_{3}} / P_{\mathrm{NH}_{3}}^{0}\right) \pi=621 / T-2.079 \\
& \log \left(z_{\mathrm{H}_{2} \mathrm{O}} / P_{\mathrm{H}_{2} \mathrm{O}}^{0}\right) \pi=1995 / T-4.140
\end{aligned}
$$

\section{1 緒言}

さきに著者らの一人1)は，尿素合成プロセスのシミュレーショ ンを試みたが, そのさい分離器および凝縮器については, $\mathrm{NH}_{3^{-}}$ $\mathrm{CO}_{2}-\mathrm{H}_{2} \mathrm{O}$ 三成分系気液平衡に関する基礎的データが不足してい

* 大阪市立大学工学部応用化学科, 大阪市住吉区杉本町

1）滰谷 堅, 矢野元威, 井本立也，化学工学協会第 33 年会 丵演要旨集符 1 分冊, p. 248(1968).
たため，尿素合成プロセス全体に関する十分な検討ができなかっ た。

$\mathrm{NH}_{3}-\mathrm{CO}_{2}-\mathrm{H}_{2} \mathrm{O}$ 系気液平衡に関しては, $60 \sim 100^{\circ} \mathrm{C}$, 常圧近傍で の実測值 ${ }^{2)}$ ，高橋ら 9 の常圧から $40 \mathrm{~atm}$ までの平衡圧，ならび

2）大塚英二, 吉村晋二, 矢加部政利, 井上 繁, 工化，63， 1214(1960)

3）高橋 達, 吉村晋二, 藤牛䝨三, 大塚英二, 工化， $65 ， 743$ (1962). 
に高橋”の 2 および $15 \mathrm{~kg} / \mathrm{cm}^{2}, 70 \sim 120^{\circ} \mathrm{C}$ での研究などがある。 後者では, アンモニアと二酸化炭素の液相中のモル分率比 $x_{\mathrm{NH}_{3}} /$ $x_{\mathrm{CO}_{2}}$ が 2 以上の範囲で実験を行ない，液相中の二酸化炭素はす ベてアンモニウムカーバメートになると仮定し，その気液平衡関 係を表わすのに溶液論で取り扱らには非常に複雑であるので奏用 的観点から経験式の表現法として van Laar 式を用い計算式を導 いている。

ところで, 分離器および凝縮器の工業操作条件としては, 非循 環, 半循環および完全循環などにより多少の違いはあるが, 圧力 $15 \sim 20 \mathrm{~kg} / \mathrm{cm}^{2}$, 温度 $100 \sim 140^{\circ} \mathrm{C}$ が一般に用いられている。

そこで本報では, 圧力 $20 \mathrm{~kg} / \mathrm{cm}^{2}$, 温度 $100 \sim 140^{\circ} \mathrm{C}, 1<x_{\mathrm{NH}_{3}} /$ $x_{\mathrm{CO}_{2}}<8$ の範囲で $\mathrm{NH}_{3}-\mathrm{CO}_{2}-\mathrm{H}_{2} \mathrm{O}$ 系の気液平衡を実測し，その等 温溶解度曲線を求めるとともに経験式の表現法として van Laar 式を用い，本条件下での気液 平 衡関 係を推算する実験式を求め た。

前に述べたよらに，高橋は $\mathrm{NH}_{3}-\mathrm{CO}_{2}-\mathrm{H}_{2} \mathrm{O}$ 系を現然に近い成分 を取り， $\mathrm{NH}_{3}-\mathrm{NH}_{4} \mathrm{CO}_{2} \mathrm{NH}_{2}-\mathrm{H}_{2} \mathrm{O}$ 系として取り扱っているが，本 実験では，実在する化学種にかかわらず $\mathrm{NH}_{3}, \mathrm{CO}_{2}$ および $\mathrm{H}_{2} \mathrm{O}$ の三成分として取り扱った。その理由は，後で述べる分析法によ り実在化学種はすべて $\mathrm{NH}_{3}, \mathrm{CO}_{2}$ および $\mathrm{H}_{2} \mathrm{O}$ の三成分としてガ スクロマトグラフにより簡単に分析できること，また，凝縮器よ り合成塔にリサイクルされる化学種は $\mathrm{NH}_{3}, \mathrm{CO}_{2}$ および $\mathrm{H}_{2} \mathrm{O}$ と して取り报われていること，による。さらにこのように取り扱っ ても相律上不都合がないため5である。

\section{2 実 . 験}

\section{1 実鈳装置}

気液平衡測定装を固 1 に示す。Aは，マグネチックスターラ 一を内蔵する内容積 $500 \mathrm{~cm}^{3}$, 材質 SUS 32 , 耐圧 $100 \mathrm{~kg} / \mathrm{cm}^{2}$ の空付オートクレーブである。 $\mathrm{C}_{1}, \mathrm{C}_{2}, \mathrm{C}_{3}$ および $\mathrm{C}_{4}$ は，材質 SUS 32 のニードルコックで, $C_{1}-C_{2}$ ならびに $C_{3}-C_{4}$ 間は，それ ぞれ $3.0 \mathrm{~cm}^{3}$ およ゙ $0.3 \mathrm{~cm}^{3}$ の既知容積をもつ気相および液相 サンプラーである。 $\mathrm{D}_{1}$ 括よび $\mathrm{D}_{3}$ は，気相和よび液相成分の分

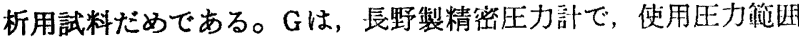
内での精度は約 3\%である。

\section{2 実験方法}

まず試料の仕込法であるが，一定組成のアンモニア，二酸化岸 素および水を個別に，あるいは混合ガスとして仕込む方法は，生 成されるアンモニウムカーバメートによって導入管の閉塞が起こ りらるため，固体打よび夜体試料を用いた。

市販特級品, 重炭酸アンモニウム，市販ポンベ（いずれも純度 99\%) から得られる液体アンモニア打よび固体二酸化炭祘, なら びに蒸留水をそれぞれ所定量すみやかに科量し，それらをあらか じめメタノールードライアイスバスで十分冷却したオートクレー ブに移したのち，オートクレーブを密閉し，冷却したまま短時間

4）高橋 達, 工化, 65, 837 (1962).

5）現実の系において各種の化学種が存在するとしても，それ ぞれ対応する化学平衡関係が成立する.たとえば， $\mathrm{NH}_{3}+\mathrm{CO}_{2}+\mathrm{H}_{2} \mathrm{O} \Longleftrightarrow \mathrm{NH}_{4} \mathrm{HCO}_{3}, \quad 2 \mathrm{NH}_{3}+\mathrm{CO}_{2}+\mathrm{H}_{2} \mathrm{O} \Longleftrightarrow$ $\left(\mathrm{NH}_{4}\right)_{2} \mathrm{CO}_{3}, 2 \mathrm{NH}_{3}+\mathrm{CO}_{2} \Longleftrightarrow \mathrm{NH}_{4} \mathrm{CO}_{2} \mathrm{NH}_{2}, \mathrm{NH}_{4} \mathrm{HCO}_{3} \Longleftrightarrow$ $\mathrm{NH}_{4}^{+}+\mathrm{HCO}_{3}^{-}, \quad \mathrm{NH}_{3}+\mathrm{HCO}_{3}^{-} \longleftrightarrow \mathrm{NH}_{4}^{+}+\mathrm{CO}_{3}^{2-}, \quad\left(\mathrm{NH}_{4}\right)_{2}$ $\mathrm{CO}_{3} \longleftrightarrow 2 \mathrm{NH}_{4}^{+}+\mathrm{CO}_{3}^{2-}, \mathrm{NH}_{4} \mathrm{CO}_{2} \mathrm{NH}_{2} \longleftrightarrow \mathrm{NH}_{4}{ }^{+}+\mathrm{NH}_{2} \mathrm{CO}_{2}^{-}$, したがって相律上の成分は 3 である。

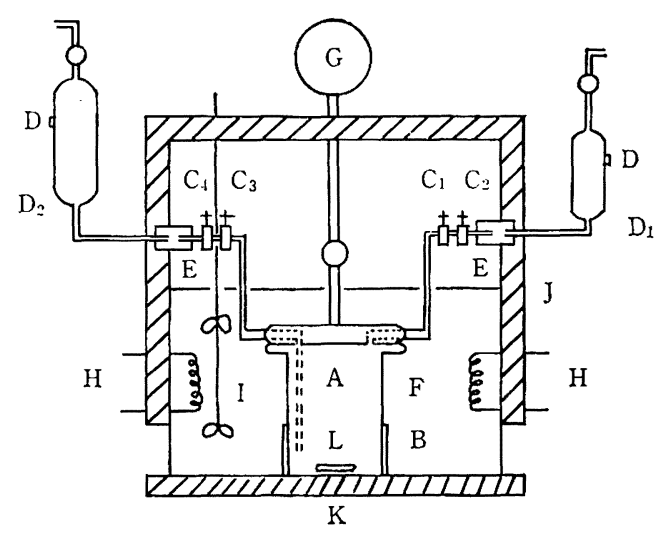

Fig. 1 Experimental apparatus

A : Autoclave, $\mathrm{B}$ : Window, $\mathrm{C}_{1}, \mathrm{C}_{2}, \mathrm{C}_{3}$ and $\mathrm{C}_{4}$ : Neadle cocks, D: Silicon rubber, $\mathrm{D}_{1}$ : Sampler for gas phase, $D_{2}$ : Sampler for liquid phase, E : Joint, $\mathrm{F}$ : Thermal medium, $\mathrm{G}$ : Pressure gauge, $\mathrm{H}$ : Heater, I : Stirrer, J : Asbestos, K:Thermostat, L : Magnetic stirrer

排気する。その後, オートクレーブの温度を室温にもどし, つい で，オートクレーブを狟温槽内にセットし，恒温槽を昇温する。 ある程度温度が上昇した所でマグネチックスターラーを作動し， 殴力 $25 \sim 30 \mathrm{~kg} / \mathrm{cm}^{2}$ になるまでさらに昇温する。つぎに, 圧力が 所定压 $20 \mathrm{~kg} / \mathrm{cm}^{2}$ になるよらに温度を調整し, 約 3 時間持続後, そのときの温度を平衡温度とした。

\section{3 気相および夜相試料の分析法}

気相サンプラー $\mathrm{C}_{1}-\mathrm{C}_{2}(3.0 \mathrm{ml})$ および液相サンプラー $\mathrm{C}_{3}-\mathrm{C}_{4}$ $(0.3 \mathrm{ml})$ をジョイントEでそれぞれ 気相ならびに液相成分分析 用試料だめ $\mathrm{D}_{1}(60 \mathrm{ml})$ 扩よび $\mathrm{D}_{2}(600 \mathrm{ml})$ と連結し， $\mathrm{C}_{1}-\mathrm{C}_{2}$, $\mathrm{C}_{3}-\mathrm{C}_{4}, \mathrm{D}_{1}$ および $\mathrm{D}_{2}$ 内を排気し, ニードルコック $\mathrm{C}_{1}$ 执よび $\mathrm{C}_{3}$ を開き $\mathrm{C}_{1}-\mathrm{C}_{2}$ 扣よび $\mathrm{C}_{3}-\mathrm{C}_{4}$ 間にそれぞれ気相括よび夜相試料を 取り出す。つぎに, ニードルコック $C_{1}$ および $C_{3}$ を閉じ， $C_{2}$ お よび $\mathrm{C}_{4}$ を開き，それぞれの陚料をあらかじめ $100^{\circ} \mathrm{C}$ に保温した $\mathrm{D}_{1}$ 执よび $\mathrm{D}_{2}$ に膨張気化させ, 前もって $100^{\circ} \mathrm{C}$ に保温した注射 器で試料を抜き取り，ガスクロマトグラフにより，アンモニア， 二酸化炭素ならびに水を定量した6)。充テン剂としてポラパック $\mathrm{Q}$ ，カラム長 $2.5 \mathrm{~m}$ ，カラム温度 $145^{\circ} \mathrm{C}$ を用いた。

\section{3 実験結果と考察}

片力 $20 \mathrm{~kg} / \mathrm{cm}^{2}$, 温度 $100 \sim 140^{\circ} \mathrm{C}$ の条件下での液相組成 $x_{i}{ }^{\prime}$ (重量分率) の測定結果を表 1 亿示す。因 2 は, $\mathrm{NH}_{3}-\mathrm{CO}_{2}-\mathrm{H}_{2} \mathrm{O}$ 三 成分系の表示に有用な值伯三手線図に表 1 の絬果をプロットした あので，等温溶解度曲線を示す。

つぎに，気相扣よび液相に持ける各成分のモル分率を表 2 に示 す。表 2 の値からつぎのよ5にして各測定点での液相成分の活量 係数を求めた4) 気相ならびに液相のモル分率をそれぞれ $y_{1}$ 扣よび $x_{1}$, 飽和蒸気

6) 存在する各種イオンや化学種はすべて $\mathrm{NH}_{3}, \mathrm{CO}_{2}$ 拉よび $\mathrm{H}_{2} \mathrm{O}$ の分子として分析できる。

7) E. Hála, J. Pick, V. Fried, O. Vilím, "Vapour-Liquid Equilibrium”, Pergamon Press Ltd. (1967) p. 122. 
Table 2 Vapor-liquid equilibrium data for $\mathrm{NH}_{3}-\mathrm{CO}_{2}-\mathrm{H}_{2} \mathrm{O}$ system at $20 \mathrm{~kg} / \mathrm{cm}^{2}$

\begin{tabular}{rccccccccc} 
Run & $\begin{array}{c}\text { Temp. } \\
\left({ }^{\circ} \mathrm{C}\right)\end{array}$ & $x_{\mathrm{NH} 3}$ & $x_{\mathrm{CO}_{2}}$ & $x_{\mathrm{H}_{2} \mathrm{O}}$ & $x_{\mathrm{NH}_{3} / x_{\mathrm{CO}_{2}}}$ & $y_{\mathrm{NH}_{3}}$ & $y_{\mathrm{CO}_{2}}$ & $y_{\mathrm{H}_{2} \mathrm{O}}$ & $y_{\mathrm{NH}_{3}} / y_{\mathrm{CO}_{2}}$ \\
\hline 1 & 100 & 0.473 & 0.066 & 0.461 & 7.2 & 1.0 & 0 & 0 & $\infty$ \\
2 & 100 & 0.552 & 0.116 & 0.362 & 4.5 & 1.0 & 0 & 0 & $\infty$ \\
3 & 110 & 0.397 & 0.066 & 0.537 & 6.0 & 1.0 & 0 & 0 & $\infty$ \\
4 & 110 & 0.515 & 0.102 & 0.383 & 4.3 & 1.0 & 0 & 0 & $\infty$ \\
5 & 120 & 0.163 & 0.160 & 0.677 & 1.0 & 0.220 & 0.706 & 0.064 & 0.28 \\
6 & 120 & 0.199 & 0.193 & 0.608 & 1.0 & 0.20 & 0.733 & 0.067 & 0.27 \\
7 & 120 & 0.265 & 0.183 & 0.552 & 1.4 & 0.550 & 0.392 & 0.058 & 1.4 \\
8 & 120 & 0.376 & 0.088 & 0.536 & 4.1 & 0.915 & 0.003 & 0.082 & 305 \\
9 & 120 & 0.372 & 0.066 & 0.562 & 5.6 & 1.0 & 0 & 0 & $\infty$ \\
11 & 130 & 0.228 & 0.116 & 0.656 & 1.9 & 0.600 & 0.300 & 0.100 & 2.0 \\
12 & 130 & 0.280 & 0.111 & 0.609 & 2.5 & 0.678 & 0.226 & 0.095 & 3.0 \\
14 & 130 & 0.305 & 0.118 & 0.577 & 2.6 & 0.724 & 0.181 & 0.095 & 4.0 \\
15 & 130 & 0.318 & 0.091 & 0.591 & 3.5 & 0.881 & 0.029 & 0.090 & 30 \\
16 & 130 & 0.314 & 0.066 & 0.620 & 4.8 & 1.0 & 0 & 0 & $\infty$ \\
17 & 140 & 0.289 & 0.066 & 0.645 & 4.4 & 0.854 & 0.071 & 0.075 & 12 \\
18 & 140 & 0.115 & 0.043 & 0.842 & 2.7 & 0.573 & 0.302 & 0.125 & 1.9 \\
19 & 140 & 0.178 & 0.067 & 0.755 & 2.6 & 0.594 & 0.296 & 0.110 & 2.0 \\
20 & 140 & 0.238 & 0.093 & 0.669 & 2.5 & 0.561 & 0.351 & 0.088 & 1.6
\end{tabular}

压を $P_{\mathrm{i}}{ }^{0}$, 系の全佂を $\pi$ とすると, $\gamma_{\mathrm{i}}$ は式（1）で表わされる。

$$
r_{\mathrm{i}}=\left(\frac{z_{\mathrm{i}} \pi}{P_{\mathrm{i}}^{0}}\right)\left(-\frac{y_{\mathrm{i}}}{x_{\mathrm{i}}}\right)
$$

ここで,

$\log z_{\mathrm{i}} \doteqdot \frac{\left(P_{\mathrm{i}}^{0}-\pi\right)\left(V_{\mathrm{iL}}-B_{\mathrm{i}}\right)}{2.303 \boldsymbol{R} T}$

$B_{\mathrm{i}}=\frac{\boldsymbol{R} T_{\mathrm{iC}}}{P_{\mathrm{iC}}}\left(0.197-0.012 T_{\mathrm{ir}}-0.4 T_{\mathrm{ir}}^{-1}-0.146 T_{\mathrm{ir}}^{-3.27}\right)$

$V_{\mathrm{IL}}=M_{\mathrm{i}} / \rho_{\mathrm{i}}$

$\rho_{\mathrm{i}}=\left(\rho_{1}{ }^{\prime} / \omega_{1}{ }^{\prime}\right) \omega_{\mathrm{i}}$

ここで, $B_{\mathrm{i}}, V_{\mathrm{iL}}, \boldsymbol{R}, T, T_{\mathrm{i} r}, T_{\mathrm{iC}}, P_{\mathrm{iC}}, \dot{M}_{\mathrm{i}}, \rho_{1}$ および $\omega_{1}$ は それぞれ成分 $\mathrm{i}$ の第 2 ビリアル係数，液体の分子容, 気体定数,

Table 1 Observed data of wt. fraction for $\mathrm{NH}_{3}, \mathrm{CO}_{2}$ and $\mathrm{H}_{2} \mathrm{O}$ in liquid phase, at $20 \mathrm{~kg} / \mathrm{cm}^{2}$

\begin{tabular}{rcccc} 
Run & $\begin{array}{c}\mathrm{Tcmp} . \\
\left({ }^{\circ} \mathrm{C}\right)\end{array}$ & $x_{\mathrm{NH}_{3}}^{\prime}$ & $x_{\mathrm{CO}_{2}}^{\prime}$ & $x_{\mathrm{H}_{2} \mathrm{O}}^{\prime}$ \\
\hline 1 & 100 & 0.418 & 0.150 & 0.332 \\
2 & 100 & 0.433 & 0.250 & 0.317 \\
3 & 110 & 0.350 & 0.150 & 0.500 \\
4 & 110 & 0.416 & 0.250 & 0.334 \\
5 & 120 & 0.123 & 0.324 & 0.553 \\
6 & 120 & 0.148 & 0.372 & 0.480 \\
7 & 120 & 0.200 & 0.360 & 0.440 \\
8 & 120 & 0.268 & 0.319 & 0.413 \\
9 & 120 & 0.320 & 0.200 & 0.480 \\
10 & 120 & 0.327 & 0.150 & 0.523 \\
11 & 130 & 0.098 & 0.230 & 0.672 \\
12 & 130 & 0.150 & 0.270 & 0.580 \\
13 & 130 & 0.194 & 0.256 & 0.550 \\
14 & 130 & 0.231 & 0.237 & 0.532 \\
15 & 130 & 0.270 & 0.200 & 0.530 \\
16 & 130 & 0.275 & 0.150 & 0.575 \\
17 & 140 & 0.103 & 0.100 & 0.797 \\
18 & 140 & 0.155 & 0.155 & 0.695 \\
19 & 140 & 0.200 & 0.201 & 0.599 \\
20 & 140 & 0.253 & 0.151 & 0.596
\end{tabular}

絶対温度, 対臨界温度, 臨界温度, 臨界圧力, 分子量, 密度およ び膨張因子 ${ }^{8)}$ であり，式（5）の'印は参照温度における值を意 味する。式（3），(4) 特よび（5）により $B_{\mathrm{i}}$ ならびに $V_{\mathrm{iL}}$ が おえられるので， $P_{i}^{0}$ が既知であれば式 (2) から所定温度にお ける $z_{\mathrm{i}}$ を, 最後に式 (1) を用いて夷測值 $x_{\mathrm{i}} ， y_{\mathrm{i}}$ から $r_{\mathrm{i}}$ を求 めることができる。

表 3 は，以上の計算に必要な各成分の物性定数である。 ところで, 式 (1) に拈いて $z_{\mathrm{i}}, P_{\mathrm{i}}{ }^{0}$ はともに温度の関数であ るが，あらかじめ任意の温度に打ける值がわかっていれば， $r_{\mathrm{i}}$ の 計算上便利である。 $P_{i}{ }^{0}$ は温度の指数関数， $z_{1}$ は複雑な形をして いるが, 指数的要素をすっていることから, 温度 $100 \sim 130^{\circ} \mathrm{C} に$ わたって計算値 $\log \left(z_{1} \pi / P_{1}{ }^{0}\right)$ を $1 / T$ に対してプロットしたとこ 万図 3 の関係を得た。図 3 から殴力 $20 \mathrm{~kg} / \mathrm{cm}^{2}$ に打ける式 (1) の係数 $\left(z_{\mathrm{i}} \pi / P_{\mathrm{i}}{ }^{0}\right)$ の温度依存性は，アンモニア拉よび水に関して それぞれ式（6）（7）で与えられることがわかった9。

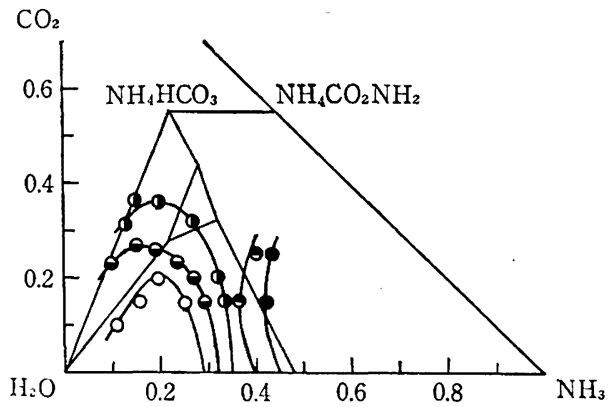

Fig. 2 Isothermal solubility curves for $\mathrm{NH}_{3}-\mathrm{CO}_{2}-\mathrm{H}_{2} \mathrm{O}$ system at $20 \mathrm{~kg} / \mathrm{cm}^{2}$

Temp. $\left({ }^{\circ} \mathrm{C}\right)$

: $100, \ominus: 110, \ominus: 120, \bigcirc: 130, \bigcirc: 140$

8) O. A. Hougen, K. M. Watson, "Chem. Process Principle”, Chapman and Hall Limited, London (1957) p. 625.

9）二酸化咸装については，测定温度がその臨界温度以上であ

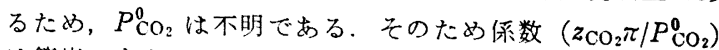
は算比できない。专た， $\gamma_{\mathrm{CO}_{2}}$ は実测値から得ら扎ない。 
Table 3 Physico-chemical properties of $\mathrm{NH}_{3}$ and $\mathrm{H}_{2} \mathrm{O}$

\begin{tabular}{|c|c|c|c|c|c|c|c|c|}
\hline $\begin{array}{l}\text { Temp. } \\
\left({ }^{\circ} \mathrm{C}\right)\end{array}$ & $T_{r_{\mathrm{NH} 3}}$ & \multicolumn{2}{|c|}{$T_{r_{\mathrm{H} 2 \mathrm{O}}}$} & $\underset{(\mathrm{ml} / \mathrm{mol})}{B_{\mathrm{NH}_{3}}}$ & \multicolumn{2}{|c|}{$\begin{array}{c}B_{\mathrm{H}_{2} \mathrm{O}} \\
(\mathrm{m} l / \mathrm{mol})\end{array}$} & $\omega_{\mathrm{NH}_{3}}$ & $\omega_{\mathrm{H}_{2} \mathrm{O}}$ \\
\hline 100 & 0.920 & \multicolumn{2}{|c|}{0.576} & -131.4 & \multicolumn{2}{|c|}{-339.4} & 0.082 & 0.126 \\
\hline 110 & 0.945 & \multicolumn{2}{|c|}{0.592} & -123.1 & \multicolumn{2}{|c|}{-316.5} & 0.073 & 0.125 \\
\hline 120 & 0.969 & \multicolumn{2}{|c|}{0.607} & -116.0 & \multicolumn{2}{|c|}{-299.8} & 0.061 & 0.124 \\
\hline 130 & 0.994 & \multicolumn{2}{|c|}{0.622} & -109.0 & \multicolumn{2}{|c|}{-279.0} & 0.050 & 0.123 \\
\hline \multirow[t]{2}{*}{$\begin{array}{l}\text { Temp. } \\
\left({ }^{\circ} \mathrm{C}\right)\end{array}$} & $\begin{array}{l}\rho_{\mathrm{NHH}_{3}{ }^{10)}} \\
(\mathrm{g} / \mathrm{m} l)\end{array}$ & $\begin{array}{c}\rho_{\mathrm{H}_{2} \mathrm{O}} \\
(\mathrm{g} / \mathrm{m} l)\end{array}$ & $\begin{array}{c}V_{\mathrm{NH}_{3}} \\
(\mathrm{ml} / \mathrm{mol})\end{array}$ & $\begin{array}{c}V_{\mathrm{H}_{2} \mathrm{O}} \\
(\mathrm{ml} / \mathrm{mol})\end{array}$ & $z_{\mathrm{NH}_{3}}$ & $z_{\mathrm{H}_{2} \mathrm{O}}$ & $\begin{array}{l}P_{\mathrm{NH}_{3}{ }^{11)}}^{0} \\
(\mathrm{~atm})\end{array}$ & $\begin{array}{l}P_{\mathrm{H}_{2} \mathrm{O}^{12)}}^{0} \\
(\mathrm{~atm})\end{array}$ \\
\hline & \multicolumn{2}{|c|}{ (at $20 \mathrm{~kg} / \mathrm{cm}^{2}$ ) } & (at 20 & $\left.\mathrm{~g} / \mathrm{cm}_{2}{ }^{2}\right)$ & & & & \\
\hline 100 & 0.445 & 0.913 & 38.2 & 19.7 & 1. 12 & 0.810 & 61.8 & 1.00 \\
\hline 110 & 0.396 & 0.906 & 42.9 & 19.9 & 1.34 & 0.815 & 74.3 & 1. 414 \\
\hline 120 & 0.331 & 0.899 & 51.4 & 20.0 & 1. 42 & 0.822 & 89.8 & 1. 959 \\
\hline 130 & 0.272 & 0.891 & 62.5 & 20.2 & 1.55 & 0.861 & 106. 9 & 2.667 \\
\hline
\end{tabular}

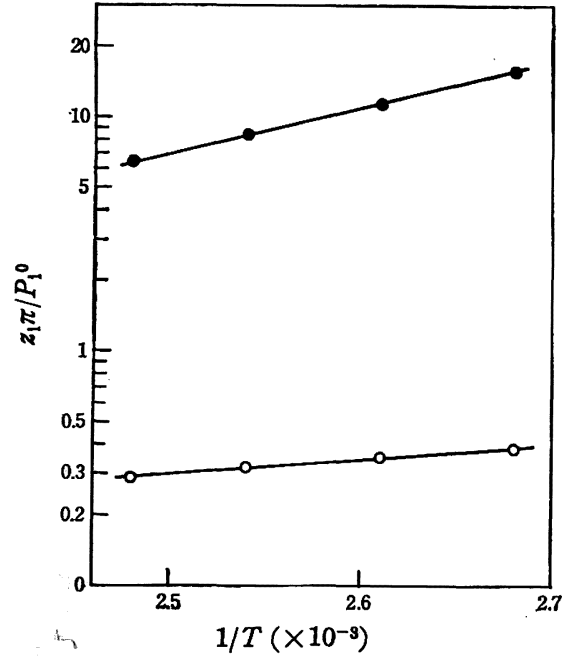

Fig. $3 z_{1} \pi / P_{i}^{0}$ vs. $1 / T$ $\pi=20 \mathrm{~kg} / \mathrm{cm}^{2}$ $: \mathrm{H}_{2} \mathrm{O}, \mathrm{O}: \mathrm{NH}_{3}$

$$
\begin{aligned}
& \log \left(z_{\mathrm{NH}_{3}} / P_{\mathrm{NH}_{3}}^{0}\right) \pi=(621 / T)-2.079 \\
& \log \left(z_{\mathrm{H}_{2} \mathrm{O}} / P_{\mathrm{H}_{2} \mathrm{O}}^{0}\right) \pi=(1995 / T)-4.140
\end{aligned}
$$

式（6），(7）を用いれば，任意の温度における実測值 $x_{1}, y_{1}$ か ら容易に $r_{i}$ が求められる。

つぎに, 活量係数 三成分系に拡張した van Laar の 2 下添式，式（8）で整理した。 一般に二成分の式を三成分に拡張する場合には，まず，二成分 系気液平衡データを別個に実測して式（8）に含まれる各種パラ メーター $A_{\imath j}$ を推定し，これを代入して得られる三成分系に対す る式（8）を三成分系気液平衡テタにより修正して完結され る。しかし, 本系では, 液相中にアンモニウムカルバメート, 炭 酸アンモニウムおよび炭酸水素アンモニウムなどが存在しうるの で, $\mathrm{CO}_{2}-\mathrm{H}_{2} \mathrm{O}, \mathrm{NH}-{ }_{3} \mathrm{H}_{2} \mathrm{O}, \mathrm{NH}_{3}-\mathrm{CO}_{2}$ の各種二成分系のデータを用 いても，その後の取り扱いに問題が残るものと思われる。そこ

10） フンモ二フの密度は約 $50^{\circ} \mathrm{C}^{11)}$ まで詳細にでており，48.89 ${ }^{\circ} \mathrm{C}$ で液体フンモニアの密度は $0.565 \mathrm{~g} / \mathrm{ml}$ である.

11) N. H. Lange, "Handbook of Chemistry", Publishers Inc., Ohio (1939) p. 1456

12) International Critical Table, Vol.3, 233(1927 1928).

13) International Critical Table, Vol.3, 234(1927 1928).

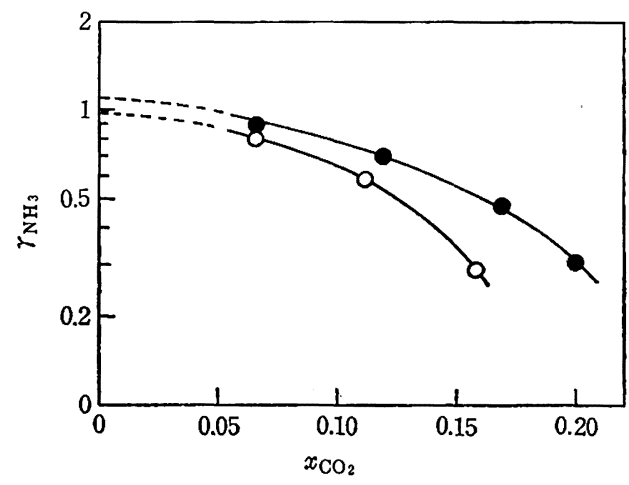

Fig. $4 \gamma_{\mathrm{NH}_{3}}$ vs. $x_{\mathrm{CO}_{2}}$, at constant $x_{\mathrm{H}_{2} \mathrm{O}}$ $: x_{\mathrm{H}_{2} \mathrm{O}}=0.6, \quad \bigcirc: x_{\mathrm{H}_{2} \mathrm{O}}=0.65$

で，三成分系のデータを直接用いて，van Laar 式のパラメータ 一を決定した。三成分系へ拡張した van Laar の 2 下添式は, 式 （8）で表わされる。

$$
\log \gamma_{1}=\frac{\begin{array}{c}
x_{2}{ }^{2}\left(A_{21} / A_{12}\right)^{2} A_{12}+x_{3}{ }^{2}\left(B_{31} / A_{13}\right)^{2} A_{13} * \\
*+x_{2} x_{9}\left(A_{21} A_{31} / A_{12} A_{13}\right)\left[A_{12}+A_{13}-\left(A_{13} / A_{31}\right) A_{32}\right]
\end{array}}{\left[x_{1}+x_{2}\left(A_{21} / A_{12}\right)+x_{3}\left(A_{31} / A_{13}\right)\right]^{2}}
$$

また，定数間にはつぎの関係がなり立つ。

$$
\frac{A_{32}}{A_{23}}=\left(\frac{A_{31}}{A_{13}}\right)\left(\frac{A_{12}}{A_{21}}\right)
$$

さて式（8）の各係数を決定するため，つぎのような方法を用 いた。たとえば， $x^{3}=$ 一定 の条件下で $\log \gamma_{1}$ を $x_{2}$ の関数とし て図示し $x_{2} \rightarrow 0$ に外插すると，このとさ得られる $\log \gamma_{1}$ は式 (8) から $A_{13} A_{31}$ との関数となる。したがって二組の $x_{3}$ から $A_{13}$ と $A_{31}$ が一義的に決定できる ${ }^{14)}$ 。同様にして二組の $x_{2}=$ 一定 の 条件から $A_{12}$ と $A_{21}$ が決定できる。最後に $A_{32}$ を最小二乗法で 求める。また， $A_{23}$ は式 (9) から計算できる。図 4,5 は, ア ンモニアに関する係数を決定するためにプロットした $\log \gamma_{\mathrm{NH}_{3}}$ $x_{\mathrm{CO}_{2}}\left(x_{\mathrm{H}_{2} \mathrm{O}}=\right.$ 一定), $\log \gamma_{\mathrm{NH}_{3}} \sim x_{\mathrm{H}_{2} \mathrm{O}}\left(x_{\mathrm{CO}_{2}}=\right.$ 一定 $)$ を例示したも のである。

これらの図と上記の方法により求めた各係数の值をつぎに示 す。

$$
A_{\mathrm{NH}_{3}, \mathrm{CO}_{2}}=-0.019
$$

14）二次式であるので, 二組の $A_{13}, A_{31}$ が得られるが，その らち実験データに適したものをとる。 
Table 4 Comparison of calculated and observed values for $y_{\mathrm{NH}_{3}}$ and $y_{\mathrm{CO}_{2}}$

\begin{tabular}{|c|c|c|c|c|c|c|c|c|c|}
\hline \multirow{2}{*}{ Run } & \multirow{2}{*}{$\begin{array}{l}\text { Temp. } \\
\left({ }^{\circ} \mathrm{C}\right)\end{array}$} & \multicolumn{2}{|c|}{$y_{\mathrm{NH}_{3}}$} & \multicolumn{2}{|c|}{$y_{\mathrm{CO}_{2}}$} & \multicolumn{2}{|c|}{$y_{\mathrm{H}_{2} \mathrm{O}}$} & \multicolumn{2}{|c|}{$y_{\mathrm{NH}_{3}} / y_{\mathrm{CO}_{2}}$} \\
\hline & & Cal. & Obs. & Cal. & Obs. & Cal. & $\overrightarrow{\text { Obs. }}$ & Cal. & Obs. \\
\hline 1 & 100 & 1.0 & 1.0 & 0 & 0 & 0 & 0 & $\infty$ & $\infty$ \\
\hline 3 & 110 & 0.973 & 1.0 & 0 & 0 & 0.007 & 0 & $\infty$ & $\infty$ \\
\hline 4 & 110 & 0.996 & 1.0 & 0 & 0 & 0.004 & 0 & $\infty$ & $\infty$ \\
\hline 5 & 120 & 0.297 & 0.220 & 0.670 & 0.706 & 0.033 & 0.064 & 0.44 & 0.31 \\
\hline 6 & 120 & 0.235 & 0.200 & 0.755 & 0.733 & 0.010 & 0.067 & 0.31 & 0.27 \\
\hline 8 & 120 & 0.957 & 0.915 & 0 & 0.003 & 0.043 & 0.082 & $\infty$ & 305 \\
\hline 9 & 120 & 1.0 & 1.0 & 0 & 0 & 0 & 0 & 8 & $\infty$ \\
\hline 11 & 130 & 0.587 & 0.600 & 0.348 & 0.300 & 0.065 & 0.100 & 1.69 & 2. 00 \\
\hline 12 & 130 & 0.745 & 0.678 & 0.214 & 0.226 & 0.041 & 0.095 & 3. 48 & 3. 00 \\
\hline 14 & 130 & 0.723 & 0.724 & 0.219 & 0.181 & 0.058 & 0.095 & 3. 30 & 4. 00 \\
\hline 15 & 130 & 0.896 & 0.881 & 0.039 & 0.029 & 0.065 & 0.090 & 23.0 & 30.4 \\
\hline 16 & 130 & 0.950 & 1.0 & 0 & 0 & 0.05 & 0 & $\infty$ & $\infty$ \\
\hline
\end{tabular}

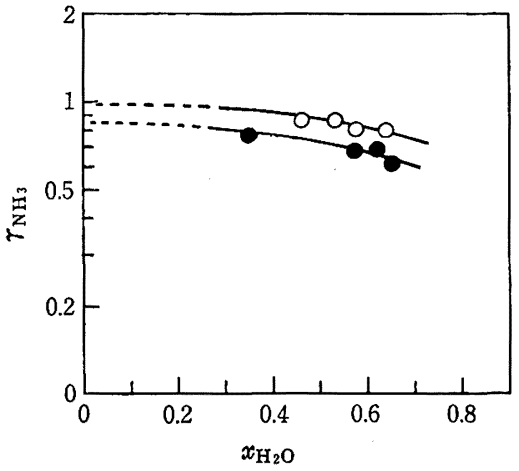

Fig. $5 \gamma_{\mathrm{NH}_{3}}$ vs. $x_{\mathrm{H}_{2} \mathrm{O}}$, at constant $x_{\mathrm{CO}_{2}}$

$: x_{\mathrm{CO}_{2}}=0.066, \quad \mathrm{O}: x_{\mathrm{CO}_{2}}=0.11$

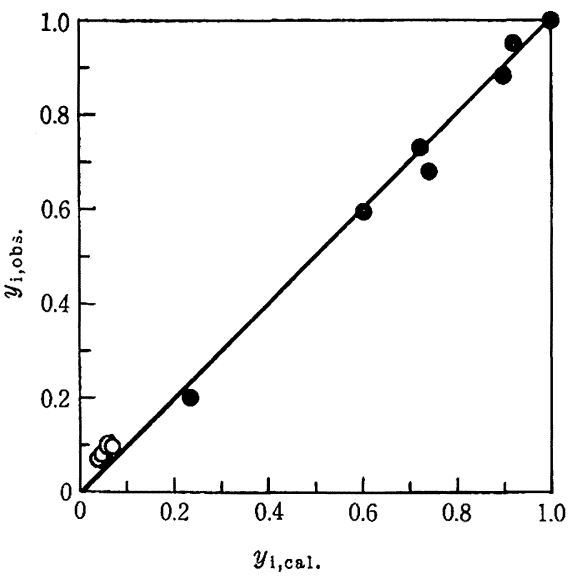

Fig. 6 Comparison of $y_{\mathrm{i}, \mathrm{cal}}$. with $y_{\mathrm{l}, \mathrm{obs}}$.

$: \mathrm{NH}_{3}, \quad \mathrm{O}: \mathrm{H}_{2} \mathrm{O}$

$A_{\mathrm{CO}_{2}, \mathrm{NH}_{3}}=0.0912$

$A_{\mathrm{NH}_{3} . \mathrm{N}_{2} \mathrm{O}}=0.0321$

$A_{\mathrm{H}_{2} \mathrm{O}, \mathrm{NH}_{3}}=0.120$

$A_{\mathrm{CO}_{2} \mathrm{H}_{2} \mathrm{O}}=2.610$

$A_{\mathrm{H}_{2} \mathrm{O}, \mathrm{CO}_{2}}=-2.034$

これらの值を用いてつぎに示す奏験式 ${ }^{12)}$ を得た。

$\log \gamma_{\mathrm{NH}_{3}}=\frac{-0.438 x_{\mathrm{CO}_{2}}^{2}+0.450 x_{\mathrm{H}_{2} \mathrm{O}}^{2}-10.0 x_{\mathrm{CO}_{2}} x_{\mathrm{H}_{2} \mathrm{O}}}{\left(x_{\mathrm{NH}_{3}}-4.80 x_{\mathrm{CO}_{2}}+3.74 x_{\mathrm{H}_{2} \mathrm{O}}\right)^{2}}$

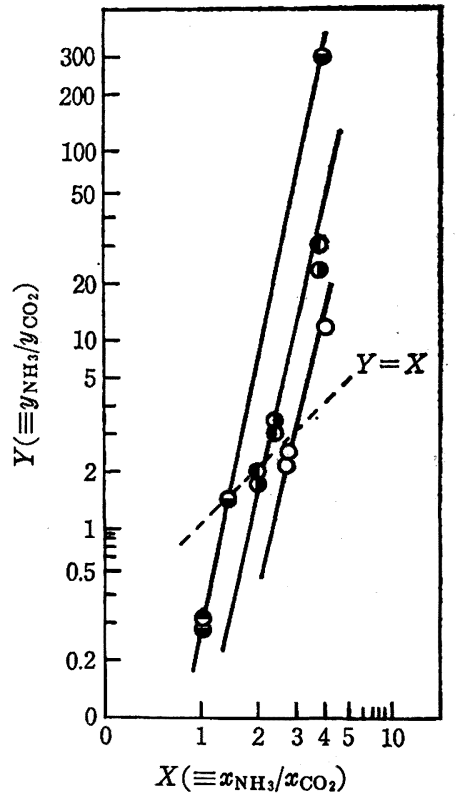

Fig. $7 \log Y$ vs. $\log X$, at constant temperature

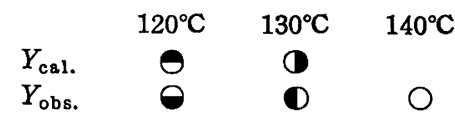

$\log \gamma_{\mathrm{H}_{2} \mathrm{O}}=\frac{-0.00859 x_{\mathrm{NH}_{3}}^{2}+3.3486 x_{\mathrm{CO}_{2}}^{2}-0.7058 x_{\mathrm{NH}_{3}} x_{\mathrm{CO}_{2}}}{\left(x_{\mathrm{H}_{2} \mathrm{O}}+0.2675 x_{\mathrm{NH}_{3}}-1.283 x_{\mathrm{CO}_{2}}\right)^{2}}$

表 2 の $x_{1}$ 值を用い，式（10）拈よび（11）から $\gamma_{\mathrm{NH}_{3}}$ および $\gamma_{\mathrm{H}_{2} \mathrm{O}}$ を計算し, 式 (1) から $y_{\mathrm{NH}_{3}}$ および $y_{\mathrm{H}_{2} \mathrm{O}}$ を逆算し, $y_{\mathrm{CO}_{2}}$ に関しては $y_{\mathrm{CO}_{2}}=1-\left(y_{\mathrm{NH}_{3}}+y_{\mathrm{H}_{2} \mathrm{O}}\right)$ として計算した値を実測値 と対比したものが表 4 と図 6 である。表 4 と図 6 から実測値と計 算值とは，ほぼ一致することがわかる。以上からアンモニウムカ ルバメート，炭酸アンモニウム，炭酸水素アンモニウムなどの液 相内化合物 ${ }^{15)}$ の種類にかかわらず，もっとも測定しやすいアンモ ニア，二酸化炭素および水の液相内含有モル分率がわかれば，式

15）これらの化合物が存在していても平衡状態では項（1）の 理由から相律から予想される自由度 $F$ はかわらない。すな わち $F=C+2-P$ において $C=3, P=2$ ゆえ $F=3$ であ る. 圧力、温度扰よび，たとえば夜相に打ける任意の 2 成 分のモル分率比で系は決定される。 
(10)，(11)，（6），（7）および（1）を用いることにより測定 温度のいかんにかかわらず，気相成分のモル分率が算定できるこ とがわかった。

図 7 はアンモニアと二酸化炭素の気相拉よび夜相におけるモル 分率比, $\left(y_{\mathrm{NH}_{3}} / y_{\mathrm{CO}_{2}}\right)=Y$ と $\left(x_{\mathrm{NH}_{3}} / x_{\mathrm{CO}_{2}}\right)=X$ の対数をそれぞれ 縌軸および横軸にとって実測值と計算值を図示したものである。 破線は $Y=X$, すなわち共沸点を示す。四 7 からアンモニアと二
酸化炭素の共沸点は, 水の量にかかわらずアンモニアと二酸化炭 素のモル分率比で決まり，その值は，120，130，140ㄷ でそれぞ

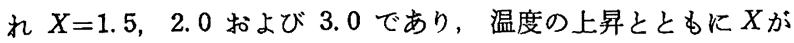
增加する傾向をすつことがわかる。

本研究を行ならにあたり，空付オートクレーブを借与していた だいた日産化学工業株式会社に謝意を表する。

\title{
Vapor-Liquid Equibrium for Ternary System of Ammonia-Carbon Dioxide-Water
}

\author{
Yuzuru Yanagisawa, Yoshio Harano and Tatsuya Imoto \\ Department of Applied Chemistry, Faculty of Engineering, Osaka City University; \\ Sugimoto-cho, Sumiyoshi-ku, Osaka-shi, Japan
}

In order to obtain the fundamental data for separational and condensing processes in urea syntheses, the vapor-liquid equilibria for the ternary system of ammonia-carbon dioxide-water were studied from $100^{\circ}$ to $140^{\circ} \mathrm{C}$ at the pressure of $20 \mathrm{~kg} / \mathrm{cm}^{2}$. And isothermal solubility curves and the empirical equations to estimate the relation of the vapor-liquid equilibrium were obtained.

The activity coefficients in the liquid phase, $\gamma_{i}$, were expressed by the following van Laar 2-suffix equations.

$$
\begin{aligned}
& \log \gamma_{\mathrm{NH}_{3}}=\left(-0.438 x_{\mathrm{CO}_{2}}^{2}+0.450 x_{\mathrm{H}_{2} \mathrm{O}}^{2}-10.0 x_{\left.\mathrm{CO}_{2} x_{\mathrm{H}_{2} \mathrm{O}}\right) /\left(x_{\mathrm{NH}_{3}}-4.80 x_{\mathrm{CO}_{2}}+3.74 x_{\mathrm{H}_{2} \mathrm{O}}\right)^{2}}\right. \\
& \log \gamma_{\mathrm{H}_{2} \mathrm{O}}=\left(0.00859 x_{\mathrm{NH}_{3}}^{2}-3.3486 x_{\mathrm{CO}_{2}}^{2}-0.7085 x_{\mathrm{NH}_{3}} x_{\mathrm{CO}_{2}}\right) /\left(x_{\mathrm{H}_{2} \mathrm{O}}+0.2675 x_{\mathrm{NH}_{3}}-1.283 x_{\mathrm{CO}_{2}}\right)^{2}
\end{aligned}
$$

From good agreement of the values calculated by Eq. (1) and (2) with the experimental results, it was found that mole fractions in the vapor phase, $y_{1}$, are well estimated from those in the liquid phase, $x_{1}$, in the experimental conditions.

The parameters, $\left(z_{1} / P_{1}^{0}\right) \pi$, which are equal to $r_{i} x_{1} / y_{1}$ and are necessary for the estimation of the vapor-liquid equilibria, were given by the following simple equations.

$$
\begin{aligned}
& \log \left(z_{\mathrm{NH}_{3}} / P_{\mathrm{NH}_{3}}^{0}\right) \pi=621 / T-2.079 \\
& \log \left(z_{\mathrm{H}_{2} \mathrm{O}} / P_{\mathrm{H}_{2} \mathrm{O}}^{0}\right) \pi=1995 / T-4.140
\end{aligned}
$$

An it is shown that the relation between $\log \left(y_{\mathrm{NH}_{3}} / y_{\mathrm{CO}_{2}}\right)$ and $\log \left(x_{\mathrm{NH}_{3}} / x_{\mathrm{CO}_{3}}\right)$ has a linearity at the constant temperature. 